\title{
PEMBERDAYAAN MASYARAKAT MELALUI EKOWISATA DI RESORT WONOLELO, TAMAN NASIONAL GUNUNG MERBABU: TANTANGAN DAN STRATEGI
}

\section{COMMUNITY EMPOWERMENT THROUGH ECOTOURISM IN WONOLELO RESORT, GUNUNG MERBABU NATIONAL PARK: CHALLENGES AND STRATEGIES}

Rusiani

Balai Taman Nasional Gunung Merbabu; J. Merbabu No.136 Boyolali, Jawa Tengah; mpwkrusiani@gmail.com

Info Artikel:

- Artikel Masuk: 13/03/18

- Artikel diterima: 24/05/18

- Tersedia Online: 28/02/18

\begin{abstract}
ABSTRAK
Sebagai upaya untuk melindungi wilayah Resort Wonolelo dari tekanan masyarakat daerah penyangga akan sumber daya alam di kawasan Taman Nasional Gunung Merbabu, dapat dilakukan pemberdayaan masyarakat dengan pengembangan ekowisata. Namun, tantangan dan strategi pemberdayaan masyarakat daerah penyangga melalui ekowisata di Resort Wonolelo belum diketahui, sehingga penelitian ini bertujuan untuk mengetahui tantangan dan strategi pemberdayaan masyarakat melalui ekowisata di Resort Wonolelo berdasarkan persepsi, motivasi, dan preferensi masyarakat. Penelitian dilakukan menggunakan metode kualitatif melalui wawancara dan observasi. Penentuan informan dilakukan secara purposive pada masyarakat di sekitar Resort Wonolelo dengan metode snowballing sebanyak 19 orang. Analisis dilakukan secara deskriptif kualitatif. Hasil penelitian menunjukkan bahwa tantangan pemberdayaan masyarakat daerah penyangga melalui ekowisata berupa kurangnya perlindungan sumber daya alam dan payung hukum pengembangan ekowisata; kurangnya kapasitas masyarakat; serta kurangnya koordinasi, peran, dan kemitraan antarinstansi Pemerintah, swasta, dan stakeholder lainnya. Strategi pemberdayaan masyarakat yang dapat dilakukan meliputi: a) perlindungan sumber daya alam dan pengesahan payung hukum pengelolaan ekowisata melalui pemberlakuan kuota pengunjung dan zonning system, pengesahan legalitas jalur pendakian Suwanting, serta penetapan Peraturan Desa hasil penerimaan jasa pengelolaan ekowisata; b) penguatan kapasitas masyarakat melalui pelatihan-pelatihan, pendampingan, studi banding, pemberian bantuan usaha, dukungan pemasaran, dan pembentukan Pokdarwis; serta c) peningkatan kemitraan antarinstansi Pemerintah, swasta, dan stakeholder lainnya terutama dalam penyediaan sarana prasarana, peningkatan kapasitas masyarakat, dan pemasaran.
\end{abstract}

Kata Kunci : Ekowisata; Pemberdayaan Masyarakat; Resort Wonolelo; Strategi; Tantangan

\section{ABSTRACT}

As an effort to protect Wonolelo Resort from people's stress on natural resources of Gunung Merbabu National Park, the community in the buffer zone can be empowered through ecotourism, such as development of such Sobleman camping ground and Suwanting track. So far, the challenges and strategies of people empowerment through ecotourism in Wonolelo Resort not known yet, therefore this research aims to explore the challenges and strategies of community empowerment in the buffer zone of Wonolelo Resort through ecotourism. The research was conducted using qualitative method with the case of Dusun Sobleman and Suwanting. The data were collected through natural observation on the community activities and interviewing 19 peoples. Analysis was conducted using descriptive qualitative technique. The research shows the main challenges in people empowerment at buffer zone through ecotourism of Sobleman camping ground and Suwanting track are lack of natural resources protection and legal framework; lack of community capacity in ecotourism; and lack of coordination, role, and partnership among government, private, and other stakeholders. Hence, this research proposes the strategies to empower the community in the buffer zone through: a) natural resources protection by providing legal framework related to ecotourism, such as zonning regulation, endorsing Suwanting track, and regulation of ecotourism income; b) strengthening community capacity through courses, accompaniment, study tour, business assistance, marketing support, and built people group of tourism; and c) enhancing collaboration among government, private, and other stakeholders particularly in infrastructure, community capacity building, and market extension.

Keyword: Challenges; Community Empowerment; Ecotourism; Strategies; Wonolelo Resort

Copyright $\odot 2016$ GJGP-UNDIP This open access article is distributed under a Creative Commons Attribution (CC-BY-NC-SA) 4.0 International license.

Cara men-sitasi (APA 6th Style):

Rusiani. (2018). Pemberdayaan Masyarakat melalui Ekowisata di Resort Wonolelo, Taman Nasional Gunung Merbabu: Tantangan dan Strategi. Jurnal Pembangunan Wilayah dan Kota, vol 14(1), 51 - 60 


\section{PENDAHULUAN}

Resort Wonolelo sebagai salah satu unit pengelolaan Taman Nasional Gunung Merbabu (TNGMb) berfungsi sebagai kawasan konservasi sumber daya alam dan ekosistemnya berdasarkan ketentuan peraturan perundang-undangan. Adanya tekanan penduduk di daerah penyangga berupa ketergantungan terhadap pemanfaatan sumber daya alam dalam rangka pemenuhan kebutuhan hidup akibat kondisi sosial ekonomi masyarakat yang relatif terbatas merupakan salah satu tantangan dalam pelaksanaan fungsi konservasi di Resort Wonolelo. Resort Wonolelo juga memiliki potensi ekowisata berupa bumi perkemahan Sobleman dan jalur pendakian Suwanting yang dapat dikembangkan. Salah satu upaya untuk melindungi wilayah Resort Wonolelo dari tekanan penduduk di daerah penyangga dapat dilakukan pemberdayaan masyarakat melalui pengembangan ekowisata sehingga diharapkan mampu meningkatkan kesejahteraan masyarakat dan tidak lagi tergantung pada sumber daya alam di kawasan TNGMb. Lokasi daerah penyangga Dusun Sobleman dan Suwanting beserta bumi perkemahan Sobleman dan jalur pendakian Suwanting dapat dilihat pada Gambar 1.

Pada hakikatnya, pemberdayaan masyarakat di sekitar kawasan konservasi atau daerah penyangga merupakan segala upaya yang bertujuan untuk terus meningkatkan keberdayaan masyarakat di sekitar kawasan konservasi atau daerah penyangga untuk memperbaiki kesejahteraannya dan meningkatkan partisipasi mereka dalam kegiatan konservasi sumber daya alam hayati dan ekosistemnya secara berkelanjutan (Departemen Kehutanan, 2008). Ekowisata sendiri merupakan suatu bentuk perjalanan wisata yang bertanggung jawab ke daerah-daerah alami yang bersifat melestarikan lingkungan, mempertahankan kesejahteraan masyarakat lokal, serta melibatkan interpretasi dan pendidikan baik bagi wisatawan maupun pengelola. Ekowisata merupakan salah satu bentuk wisata yang tepat untuk diterapkan di kawasan taman nasional karena mengedepankan aspek konservasi (TIES, 2015). Ekowisata diharapkan mampu menghasilkan pemasukan untuk kegiatan konservasi dan memberikan alternatif ekonomi bagi aktivitas-aktivitas penduduk lokal yang sebelumnya bersifat merusak alam (Kiss, 2004). Agar kegiatan pemberdayaan masyarakat dapat berjalan secara efektif, maka perlu diketahui tantangan dan strategi pemberdayaan masyarakat daerah penyangga melalui pengembangan ekowisata. Tantangan dalam pemberdayaan masyarakat melalui pengembangan ekowisata salah satunya berupa masalah perlindungan sumber daya alam karena ekowisata biasanya berlangsung di kawasan-kawasan yang dilindungi dengan keanekaragaman tinggi dan merupakan area yang rentan serta memiliki dampakdampak lingkungan yang signifikan sehingga harus dikelola secara ketat dan hati-hati, serta diawasi dan dikontrol untuk mencegah rusaknya site-site ekowisata (Wearing dan Neil, 2009). Tantangan lain berupa sulitnya komunikasi yang bersifat efektif dalam masyarakat (Obua, dkk, 2007); kejenuhan wisatawan terhadap atraksi yang sudah ada karena kurangnya kapasitas masyarakat dalam mengembangkan atraksi dan paket-paket wisata (Suarka, 2011; Goodwin dan Roe, 2001); serta kurangnya modal awal, pengetahuan, kesempatan, serta kemampuan organisasi; kurangnya jumlah wisatawan yang datang berkunjung; dan terbatasnya atraksi serta infrastruktur (Goodwin dan Roe, 2001). Masalah koordinasi para stakeholder juga menjadi tantangan tersendiri karena pengembangan ekowisata tidak akan optimal jika diserahkan sepenuhnya kepada sektor swasta dimana motivasi utamanya pada perhitungan rugi dan laba, namun juga tidak akan berkembang jika didominasi oleh sektor Pemerintah, sehingga diperlukan kerja sama dan koordinasi yang baik antara pengelola kawasan, swasta, Pemerintah Daerah, dan masyarakat (Trihayuningtyas, 2010, dalam Setyadi, 2012).

Faktor-faktor kunci bagi kesuksesan pemberdayaan masyarakat melalui pengembangan ekowisata antara lain berupa pengaturan kelembagaan; regulasi yang berkaitan dengan konservasi; kesadaran lingkungan yang tinggi; kemitraan; partisipasi masyarakat; kolaborasi dengan pihak lain; sikap positif, kemauan dan kesadaran masyarakat; peluang pasar; adanya keuntungan yang mengalir secara langsung kepada masyarakat; serta adanya aktivitas yang memadukan antara wisata, budaya, serta konservasi alam (Hiwasaki, 2006; Okazaki, 2008; Obua, dkk, 2007). Strategi pengelolaan ekowisata di antaranya mencakup pengembangan produk, penyediaan sarana prasarana wisata, pengelolaan layanan pengunjung, pemasaran wisata, serta perlindungan sumber daya alam, sehingga akan membawa 
dampak-dampak yang positif secara ekonomi, sosial, lingkungan dan budaya (Reid, dkk, dalam Oladeji, 2015). Pengembangan produk wisata dilakukan untuk mengantisipasi kejenuhan wisatawan terhadap atraksi wisata yang sudah ada. Hal tersebut dapat dilakukan antara lain melalui pembuatan paket-paket ekowisata dan atraksi seperti bird watching, bersepeda keliling wilayah pedesaan, mempelajari seni budaya dan makanan tradisional, mempelajari jejak satwa liar, serta melihat keanekaragaman tumbuhan (botany tour) (Suarka, 2011; Goodwin dan Roe, 2001). Kesadaran untuk menjaga dan melindungi sumber daya alam juga menentukan keberhasilan pemberdayaan masyarakat (Jaafar, dkk, 2015) dan dapat dilakukan melalui pembatasan jumlah pengunjung (kuota) sesuai dengan daya dukung lingkungan (carrying capacities) dan pemberlakuan zonning system untuk membatasi pergerakan pengunjung serta melindungi sumber daya alam hayati (Petric dan Mandic, 2014).

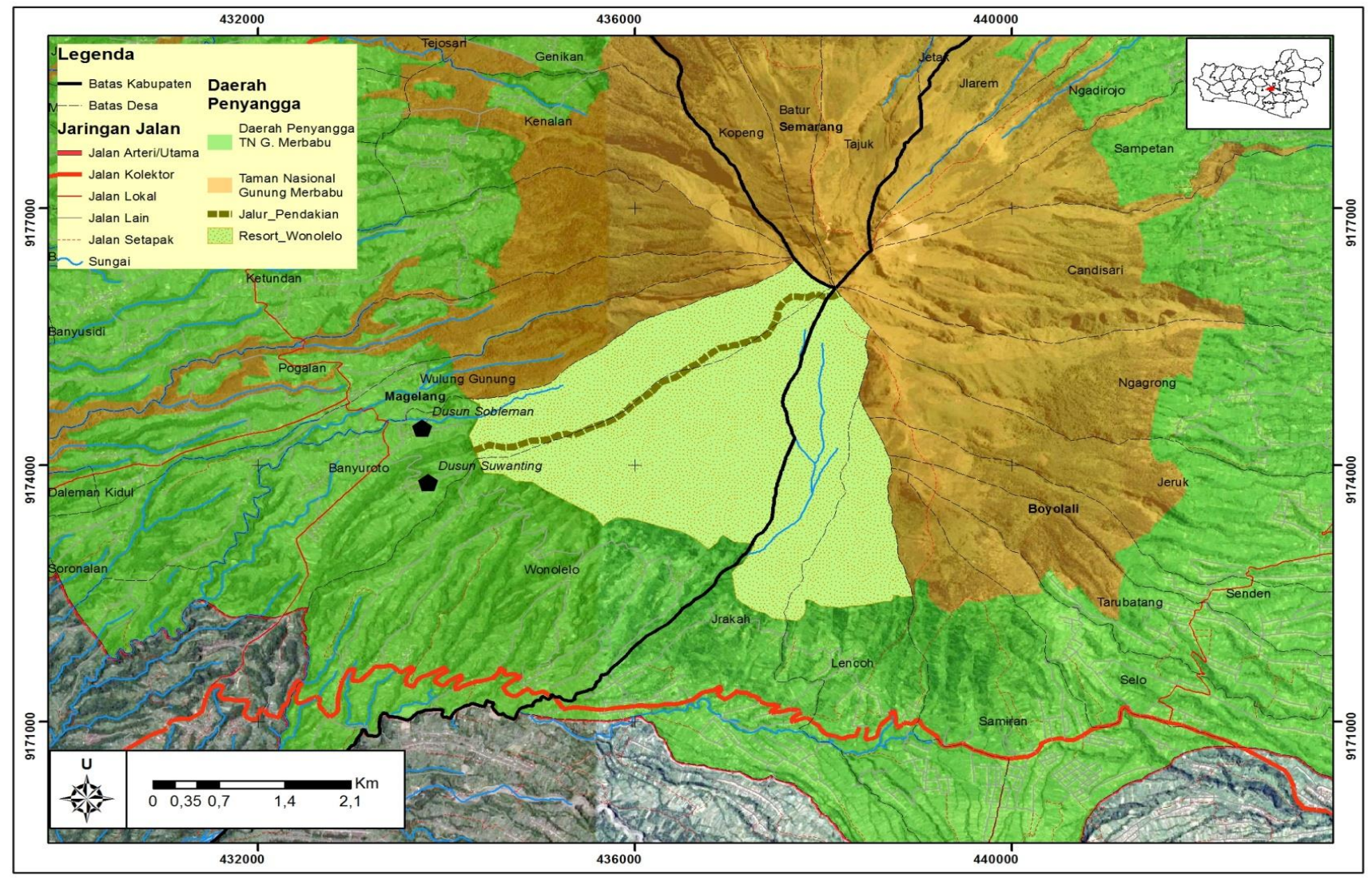

Gambar 1. Lokasi Daerah Penyangga Dusun Sobleman dan Suwanting (Hasil Analisis Peneliti, 2016)

Sejauh ini, tantangan dan strategi pemberdayaan masyarakat daerah penyangga melalui pengembangan ekowisata di Resort Wonolelo belum diketahui. Kajian atau penelitian mengenai tantangan dan strategi pemberdayaan masyarakat daerah penyangga melalui pengembangan ekowisata di Resort Wonolelo juga belum pernah dilakukan, sehingga diperlukan adanya penelitian mengenai hal-hal apa saja yang menjadi tantangan dan bagaimana strategi pemberdayaan masyarakat yang dapat dilakukan. Dengan demikian, penelitian ini bertujuan untuk mengetahui tantangan dan strategi pemberdayaan masyarakat daerah penyangga melalui pengembangan ekowisata di Resort Wonolelo, TNGMb. Hasil penelitian diharapkan dapat memberikan inspirasi ilmu pengetahuan berupa bentuk-bentuk tantangan dan strategi pemberdayaan masyarakat melalui pengembangan ekowisata di daerah penyangga suatu kawasan konservasi khususnya di Resort Wonolelo, Taman Nasional Gunung Merbabu yang belum pernah dilakukan sebelumnya. 


\section{DATA DAN METODE}

Pendekatan penelitian yang dilakukan berupa pendekatan deskriptif kualitatif yang menekankan pada tujuan eksploratif mengenai tantangan dan strategi pemberdayaan masyarakat daerah penyangga melalui pengembangan bumi perkemahan Sobleman dan jalur pendakian Suwanting. Lokasi penelitian ini berada di bumi perkemahan Sobleman dan jalur pendakian Suwanting, serta Dusun Sobleman dan Dusun Suwanting, Desa Banyuroto. Data-data primer diperoleh melalui wawancara semi terstruktur dan observasi (Moleong, 2012), sedangkan data sekunder diperoleh melalui telaah dokumen dan studi literatur. Informan penelitian ditentukan dengan metode purposive dan dilakukaan secara snowballing sebanyak 19 orang meliputi warga Dusun Sobleman dan Dusun Suwanting, pengurus kelompok tani dan paguyuban pengelola ekowisata bumi perkemahan Sobleman dan jalur pendakian Suwanting, perangkat pemerintahan mulai dari tingkat Dusun, Desa, serta Kecamatan setempat, serta Balai TNGMb dan Dinas Pariwisata Kabupaten Magelang. Ketua kelompok tani dan paguyuban berperan sebagai informan kunci dan selanjutnya mereka menunjuk informan lanjutan yang merupakan perwakilan dari kelompok-kelompok masyarakat yang berpartisipasi dalam pengembangan bumi perkemahan Sobleman dan jalur pendakian Suwanting seperti perwakilan dari kelompok guide, porter, jasa angkutan, penjual makanan, dan persewaan peralatan mendaki gunung. Data-data kualitatif yang diperoleh selanjutnya diolah melalui tahapan reduksi data, penyajian data (data display), serta verifikasi data (conclusion drawing and verification) (Miles dan Huberman, 1992).

Bumi perkemahan Sobleman terletak dekat dengan Dusun Sobleman, sedangkan jalur pendakian Suwanting terletak di wilayah Resort Wonolelo dengan pintu masuknya melalui Dusun Suwanting, Desa Banyuroto. Keduanya mulai dikelola oleh masyarakat mulai tahun 2015 dengan kapasitas dan kemampuan yang terbatas. Pihak Balai TNGMb selaku pemangku kawasan TNGMb belum banyak terlibat dalam pengembangan potensi ekowisata tersebut. Atraksi utama bumi perkemahan Sobleman berupa area bumi perkemahan seluas 10,7 Ha. Bumi perkemahan Sobleman memiliki kontur yang cukup datar sehingga dapat dimanfaatkan untuk kegiatan berkemah baik untuk keluarga maupun kelompok perorangan dengan kapasitas \pm 400 orang. Selain tempat untuk berkemah, tersedia juga jalur untuk melakukan aktivitas tracking. Jalur pendakian Suwanting sudah mulai ada sejak tahun 1990, akan tetapi akibat faktor kepengurusan yang tidak tersusun dengan baik menyebabkan jalur pendakian ini tidak berkembang mulai tahun 1993. Pada tahun 2015, jalur pendakian ini mulai dibuka kembali melalui inisiatif warga Dusun Suwanting karena banyak diminati oleh kalangan pendaki. Kondisi topografi di jalur pendakian ini bervariasi mulai dari landai, curam, hingga sangat curam, dan bersifat single track atau tidak bercabangcabang sehingga memiliki resiko tersesat yang sangat kecil bagi para pendaki. Atraksi utama ekowisata jalur pendakian Suwanting berupa track atau jalur pendakian menuju puncak Gunung Merbabu sepanjang \pm $5 \mathrm{~km}$ dihitung dari batas kawasan TNGMb hingga puncak Trianggulasi. Gambar aktivitas ekowisata di bumi perkemahan Sobleman dan jalur pendakian Suwanting dapat dilihat pada Gambar 2.



(A)

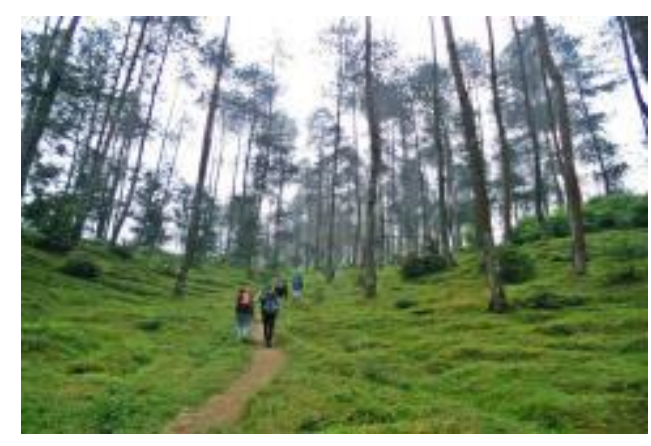

(B)

Gambar 2. Wisata Perkemahan di Bumi Perkemahan Sobleman (A) dan Wisata Pendakian di Jalur Pendakian Suwanting (B) (Hasil Observasi Lapangan, 2017) 


\section{HASIL DAN PEMBAHASAN}

Tantangan pemberdayaan masyarakat daerah penyangga khususnya Dusun Sobleman dan Suwanting melalui pengembangan ekowisata bumi perkemahan Sobleman dan jalur pendakian Suwanting antara lain sebagai berikut:

1. Kurangnya perlindungan sumber daya alam, belum disahkannya legalitas jalur pendakian Suwanting, dan payung hukum pembagian hasil retribusi jasa wisata dalam masyarakat

Minimnya kegiatan perlindungan sumber daya alam seperti kurangnya dukungan kebijakan dalam kegiatan pengembangan ekowisata yang meliputi belum diberlakukannya aturan mengenai kuota pengunjung dan zonning system untuk melindungi sumber daya alam dapat mengakibatkan rusaknya sumber daya alam yang ada sehingga ekowisata tidak berkelanjutan dan upaya pemberdayaan masyarakatpun akan terhenti. Legalitas jalur pendakian Suwanting yang belum disahkan membuat wisatawan ragu untuk berkunjung dan menghambat pengembangan ekowisata serta upaya pemberdayaan masyarakat. Belum adanya payung hukum berupa peraturan desa (Perdes) mengenai distribusi hasil penerimaan jasa pengelolaan wisata dapat memunculkan konflik di masyarakat sehingga suasana menjadi tidak kondusif bagi upaya pemberdayaan masyarakat melalui pengembangan ekowisata. Beberapa kutipan wawancara dengan informan dapat dilihat di bawah ini.

Kuota belum, untuk Sobleman juga belum, untuk Suwanting belum, belum ada... $(S Y, W 8,10-05-2017,28)$

...sekarang terutama di jalur Suwanting kan belum secara total walaupun sudah jual tiket dan diakui, tetapi belum secara total resmi dapat ya... istilahnya sertifikat atau ijazah (legalitas) dari Taman Nasional, oh bahwa Suwanting ini deal resmi. Itu masih dipertanyakan beberapa organisasi dan pendaki tamu-tamu saya, saya cuma masih menjelaskan saja, kan ya Taman Nasional butuh proses kan,.. (DI,W13,15-05-2017,166)

...untuk kompensasi ke desa ini dulu sudah disepakati tapi belum bisa berjalan dengan baguslah..., katakanlah dari desa juga tidak bisa menuntut secara tertib, ya mungkin itu dari desa hanya tiap berapa bulan itu dikasih berapa itu yang dari Suwanting,... (SN,W3,06-05-2017,26)

2. Kurangnya kapasitas masyarakat daerah penyangga dalam hal pengetahuan dan pengalaman dalam mengembangkan ekowisata, modal usaha, dan peran kaum perempuan

Belum adanya pengembangan produk wisata dan kurangnya pemasaran wisata disebabkan oleh kurangnya kapasitas atau kemampuan yang dimiliki oleh masyarakat untuk mengembangkan ekowisata baik berupa pengalaman, pengetahuan, modal usaha, serta peran kaum perempuan. Hal ini tentu saja menjadi tantangan dalam upaya pemberdayaan masyarakat daerah penyangga melalui pengembangan ekowisata seperti dikutip dari beberapa informan di bawah ini.

Yang lain itu, saya kira kendalanya itu mencari dana. Kalau ada yang bisa memberi kalau untuk pelatihan, pemberian pelatihan untuk kelompok pengelola itu memang saya harapkan, tapi bukan hanya untuk pelatihan semata tapi harus dipraktekkan, pendampingan itu paling tidak sampai pertengahan... jangan sampai putus di jalan, paling nggak itu ya $60 \%$ ke atas sudah berjalan.(SH,W5,06-05-2017,102-103)

Itu terus terang ya dari SDM-nya masyarakat ya masih rendah, SDM juga membutuhkan pelatihan-pelatihan seperti cara pengelolaan jalur atau mungkin cara penanganan evakuasi, pokoknya butuh pelatihan-pelatihan. (ST,W15,17-05-2017, 109-110)

... Ya kalau ibu-ibu atau ibu rumah tangga dia juga perlu dilibatkan karena apa..., mereka butuh pengalaman cara ngomong, cara masak, kalau penjualan sayur kita paketkan gimana pengemasannya, biar tamu itu yang datang menarik untuk membeli sayur kita, itu juga butuh sharing dan motivator seperti itu memang butuh, tapi kita masih kurang di itu, SDM nya masih lemah lah. (DI,W13,15-05-2017, 159 - 160; 162-167; 169) 
3. Kurangnya koordinasi, peran, dan kemitraan antarinstansi Pemerintah, swasta, dan stakeholder lainnya

Peran Pemda dan Pemerintah Pusat serta stakeholder lainnya yang direpresentasikan oleh Pemerintah Desa, Pemerintah Kecamatan, Penyuluh Kecamatan, Balai TNGMb, Dinas Pariwisata, BPBD, swasta, LSM, dan perguruan tinggi, dalam pengembangan ekowisata masih kurang terutama dalam hal perijinan pembangunan sarana prasarana wisata, pendanaan, penyediaan tenaga ahli, serta pemasaran ekowisata. Kemitraan untuk mengembangkan ekowisata terutama dalam hal penyediaan sarana prasarana dan pemasaran ekowisata masih kurang seperti kemitraan dengan calon-calon wisatawan yang potensial berupa sekolah-sekolah untuk meningkatkan kunjungan wisatawan di bumi perkemahan Sobleman masih kurang. Kemitraan antara Pemda dan Pemerintah Pusat (dalam hal ini direpresentasikan oleh Balai TNGMb) juga belum terjalin secara optimal padahal Pemda memiliki dana desa untuk mengembangkan sarana prasarana dan tenaga ahli, sedangkan Balai TNGMb sebagai pemangku kawasan dapat memberikan kemudahan perijinan untuk membangun sarana prasarana. Peran swasta dalam pengembangan bumi perkemahan Sobleman dapat dikatakan belum ada, sedangkan peran swasta dalam pengembangan jalur pendakian Suwanting masih sangat terbatas yaitu masyarakat Dusun Suwanting bekerja sama dengan para sopir angkutan yang berada di terminal, stasiun, maupun bandara di Yogyakarta dan Semarang untuk menyediakan jasa angkutan dengan harga yang lebih terjangkau bagi para pendaki. Kerja sama dengan pihak swasta dalam hal lainnya belum ada dan masyarakat Dusun Suwanting sendiri memiliki kesepakatan bahwa pihak swasta tidak boleh masuk terlibat jauh dalam pengembangan ekowisata karena mereka khawatir pihak swasta ini akan menguasai usaha yang ada dan masyarakat lokal menjadi terabaikan. Kutipan-kutipan wawancara dengan informan di antaranya dapat dilihat di bawah ini.

.... Kalau bisa itu... menurut saya misalnya saya ada minta bantuan dari... entah dari dana desa atau dana dari kabupten untuk membuat apa di situ, itu kalau bisa itu ijin itu dipermudah, misalnya dari Taman Nasional sendiri. Misalnya saya minta ijin itu harus didukung, bukan dipersulit. (SH,W5,06-05-2017, 38; 94-96; 98-99; 100-103)

Kemitraan ya perlu itu sangat perlu, kan Taman Nasional tidak bisa bekerja sendiri, tapi kan jenis-jenis kemitraan kan juga harus perlu kita pelajari bagaimana, ada kemanfaatannya tidak..., dan selama ini belum ada. (SY,W8,10-05-2017)

Tantangan dalam pemberdayaan masyarakat daerah penyangga melalui pengembangan ekowisata berupa masalah perlindungan sumber daya alam ini seperti yang diungkapkan oleh Wearing dan Neil (2009) bahwa ekowisata yang biasanya berlangsung di kawasan-kawasan yang dilindungi, memiliki keanekaragaman yang tinggi, serta merupakan area yang rentan seharusnya dikelola secara ketat dan hatihati, serta diawasi dan dikontrol untuk mencegah rusaknya site-site ekowisata tersebut. Kurangnya kapasitas masyarakat daerah penyangga dalam hal pengetahuan dan pengalaman dalam mengembangkan ekowisata, modal usaha, dan peran kaum perempuan ini mendukung pernyataan Suarka (2011) serta Goodwin dan Roe (2001) bahwa kejenuhan wisatawan terhadap atraksi yang sudah ada karena kurangnya kapasitas masyarakat dalam mengembangkan atraksi dan paket-paket wisata; kurangnya modal awal, pengetahuan, kesempatan, serta kemampuan organisasi; dan terbatasnya atraksi serta infrastruktur. Kurangnya koordinasi, peran, dan kemitraan antarinstansi Pemerintah, swasta, dan stakeholder lainnya mendukung pernyataan Obua, dkk, (2007) bahwa tantangan dalam pengembangan ekowisata salah satunya berupa sulitnya komunikasi yang bersifat efektif dalam masyarakat. Pengembangan ekowisata tidak akan optimal jika diserahkan sepenuhnya kepada sektor swasta dan tidak akan berkembang jika didominasi oleh sektor Pemerintah. Oleh karena itu, kerja sama dan koordinasi yang baik antara pengelola kawasan, swasta, Pemerintah Daerah, dan masyarakat sangatlah diperlukan (Trihayuningtyas, 2010, dalam Setyadi, 2012).

Berdasarkan tantangan-tantangan yang ada, maka bentuk-bentuk strategi pemberdayaan masyarakat Dusun Sobleman dan Suwanting melalui pengembangan bumi perkemahan Sobleman dan jalur pendakian Suwanting dapat dirumuskan sebagai berikut:

1. Perlindungan sumber daya alam dan pengesahan payung hukum dalam pengembangan ekowisata 
Strategi ini dilakukan dengan memberlakukan aturan mengenai kuota pengunjung dan zonning system untuk membatasi dan mengatur pergerakan pengunjung, mengesahkan legalitas jalur pendakian Suwanting, serta menetapkan payung hukum berupa peraturan desa (Perdes) mengenai distribusi hasil penerimaan jasa pengelolaan wisata. Strategi ini diperlukan untuk menciptakan suasana kondusif bagi keberlanjutan proses pengembangan ekowisata dan upaya pemberdayaan masyarakat yang dilakukan karena dapat melindungi site ekowisata dari kerusakan, menghilangkan keraguan wisatawan untuk berkunjung, dan mencegah konflik pada masyarakat. Dukungan kebijakan ini dapat dilakukan oleh Balai TNGMb sebagai pemangku kawasan TNGMb dan Pemerintah Desa Banyuroto.

\section{Penguatan kapasitas masyarakat daerah penyangga}

Penguatan kapasitas masyarakat daerah penyangga dapat dilakukan dengan memberikan pelatihan-pelatihan (meliputi pelatihan pengembangan wisata, pengolahan makanan, keterampilan berbahasa inggris, pengelolaan sampah, pelatihan SAR, pelatihan keterampilan pemandu dan porter, pelatihan di bidang pertanian dan peternakan untuk mengangkat potensi selain ekowisata); pendampingan intensif oleh tenaga yang ahli dalam pengembangan ekowisata; studi banding ke lokasi pengembangan ekowisata berbasis masyarakat yang sudah lebih maju; pemberian bantuan usaha (berupa penambahan kredit modal usaha, peralatan berkemah dan sablon, serta peralatan pengolahan dan pengemasan makanan); meningkatkan dukungan pemasaran (seperti keikutsertaan dalam pameran dan promosi baik melalui media cetak seperti leaflet, banner, brosur, maupun media elektronik seperti website dan media sosial); serta pembentukan Pokdarwis agar upaya pemberdayaan masyarakat di tingkat desa menjadi lebih terpadu. Meskipun belum memiliki pengalaman kerja di sektor wisata, masyarakat di daerah penyangga memiliki keterbukaan untuk menerima informasi dan mengikuti program-program pengembangan ekowisata. Penguatan kapasitas sumber daya manusia ini bertujuan agar masyarakat memiliki keterampilan untuk mengembangkan ekowisata secara profesional dengan membuat paketpaket wisata dan atraksi yang baru dengan tetap mengedepankan aspek kelestarian lingkungan dan nilainilai sosial budaya melalui sinergi antara ekowisata dengan sektor pertanian dan mengangkat potensi lokal lainnya seperti paket wisata mempelajari budidaya sayuran, budidaya anggrek, berkemah, tracking, live in untuk mempelajari pembuatan makanan khas tradisional dan kesenian lokal, outbond, jembatan sunset, "sayur petik sendiri", rumah pohon, budaya dan kesenian lokal, serta gardu pandang (pemasaran paketpaket wisata dan atraksi yang baru ini dapat digabungkan dengan jenis atraksi yang sudah ada seperti bumi perkemahan Sobleman, jalur pendakian Suwanting, dan obyek-obyek wisata di sekitar Resort Wonolelo seperti Ketep Pass, agrowisata strawberry, dan air terjun Kedung Kayang); mampu memasarkan ekowisata lebih luas dan meningkatkan kunjungan wisatawan; mampu menyediakan barang dan jasa keperluan wisatawan dengan lebih lengkap dan profesional; mampu meningkatkan peran kaum perempuan dalam pengembangan ekowisata; serta mampu menata kelembagaan kelompok sehingga lebih efektif dan efisien. Penguatan kapasitas sumber daya manusia ini dapat diberikan oleh instansi Pemerintah seperti Balai TNGMb, Pemerintah Desa, Pemerintah Kecamatan, Dinas Pariwisata, BPBD, Badan SAR, LSM, perguruan tinggi, maupun pihak swasta.

\section{Peningkatan koordinasi, peran, dan kemitraan antarinstansi Pemerintah, swasta, dan stakeholder lainnya}

Peningkatan koordinasi, peran, dan kemitraan antarinstansi Pemerintah, swasta, dan stakeholder lainnya dapat dilakukan antara lain Balai TNGMb dapat memberikan kemudahan dalam proses perijinan pembangunan sarana prasarana; Pemerintah Desa dapat mendukung pendanaan untuk membangun sarana prasarana melalui dana desa; Pemerintah Kecamatan dapat mengarahkan pengaturan anggaran dalam dana desa untuk mengembangkan ekowisata; Dinas Pariwisata, Penyuluh Kecamatan, Perguruan Tinggi, swasta dan LSM dapat memberikan pembinaan melalui pelatihan-pelatihan, pendampingan, dan bantuan modal usaha; BPBD dan SAR dapat memberikan pembinaan melalui pelatihan penanganan evakuasi pengunjung serta bencana; biro wisata, event organizer, dan sekolah-sekolah dapat berperan dalam hal pemasaran wisata; serta penyedia jasa angkutan dapat berperan menyediakan jasa angkutan 
yang terjangkau bagi para pendaki. Kemitraan ini dilakukan dengan tujuan untuk memudahkan penyediaan sarana prasarana yang menunjang pengembangan ekowisata; memudahkan upaya peningkatan kapasitas masyarakat dalam pemberdayaan masyarakat melalui pengembangan ekowisata; serta memperluas jaringan pemasaran ekowisata sehingga meningkatkan kunjungan wisatawan. Pemerintah didorong untuk meningkatkan dukungan dan peran aktifnya dalam pengembangan ekowisata karena terdapat potensi pemasukan bagi Pendapatan Asli Daerah (PAD) dan Penerimaan Negara Bukan Pajak (PNBP) yang cukup menjanjikan jika dikelola dengan baik. Selain itu, paradigma pemberdayaan masyarakat yang memungkinkan masyarakat untuk berpartisipasi dalam mengelola sumber daya alam sehingga dapat ikut berperan dalam pembangunan dan menjadi masyarakat yang mandiri akan meringankan beban Pemerintah dikarenakan Pemerintah sendiri tidak bisa sepenuhnya membiayai seluruh pembangunan. Selain itu, biaya untuk konservasi lingkungan sendiri dapat disuplai dari adanya aktivitas ekowisata ini (Sumaryadi, 2005; Kiss, 2004).

Strategi perlindungan sumber daya alam mutlak diperlukan karena pada dasarnya ekowisata merupakan bagian dari pariwisata berkelanjutan (sustainable tourism) yang terintegrasi dengan tiga pilar pembangunan berkelanjutan (sustainable development) yaitu ekonomi, sosial, serta lingkungan. Selain itu, ekowisata bumi perkemahan Sobleman dan jalur pendakian Suwanting berada di kawasan konservasi sehingga harus dikelola secara ketat dan hati-hati, serta diawasi untuk mencegahnya dari kerusakan (Wearing dan Neil, 2009). Pengesahan payung hukum seperti pengesahan legalitas jalur pendakian Suwanting dan Perdes mengenai distribusi hasil penerimaan jasa wisata, serta peningkatan kemitraan dilakukan untuk menciptakan suasana kondusif bagi upaya pemberdayaan masyarakat melalui pengembangan ekowisata, karena faktor kunci bagi kesuksesan ekowisata berbasis masyarakat di antaranya berupa pengaturan kelembagaan, regulasi terkait konservasi, kemitraan, dan kolaborasi dengan pihak lain (Hiwasaki, 2006; Okazaki, 2008; Obua, dkk, 2007). Bentuk-bentuk strategi pemberdayaan masyarakat melalui pengembangan ekowisata bumi perkemahan Sobleman dan jalur pendakian Suwanting juga mendukung pendapat Jaafar, dkk, (2015) bahwa peningkatan partisipasi aktif masyarakat melalui peningkatan kapasitas masyarakat, adanya perlindungan sumber daya alam, dan kemitraan antara masyarakat, Pemerintah, dan stakeholder lainnya mampu mendukung keberhasilan upaya pemberdayaan masyarakat melalui pengembangan ekowisata. Kapabilitas masyarakat dalam mengelola ekowisata sangatlah penting karena masyarakat lokal merupakan aktor kunci dalam pengembangan ekowisata dimana berperan sebagai penyedia atraksi wisata dan penentu kualitas produk wisata tersebut (Direktorat Pemanfaatan Jasa Lingkungan dan Wisata Alam, 2010; Situmorang dan Mirzanti, 2012; Snyman, 2014; Damanik dan Weber, 2006). Pemberdayaan masyarakat melalui pengembangan wisata dapat dilakukan dengan cara memberikan dukungan langsung bagi usaha skala kecil dan mikro seperti pemberian kredit, pelatihan-pelatihan, dukungan pemasaran, adanya kemitraan antara masyarakat dan pihak swasta, serta dukungan Pemerintah (Goodwin dan Roe, 2001).

\section{KESIMPULAN}

Pemberdayaan masyarakat daerah penyangga melalui pengembangan ekowisata di Resort Wonolelo, TNGMb memiliki tantangan tersendiri karena aktivitas ekowisata berlangsung pada kawasan konservasi dengan keanekaragaman hayati yang tinggi dan bersifat rentan, sehingga jika tidak dikelola dengan hati-hati justru akan merusak site ekowisata tersebut (Wearing dan Neil, 2009). Kurangnya perlindungan sumber daya alam dan payung hukum dalam pengembangan ekowisata; kurangnya kapasitas masyarakat daerah penyangga dalam mengembangkan ekowisata; serta kurangnya koordinasi, peran, dan kemitraaan antarstakeholder menjadi tantangan utama dalam upaya pemberdayaan masyarakat daerah penyangga melalui pengembangan ekowisata di Resort Wonolelo, TNGMb. Strategi pemberdayaan masyarakat yang dapat dilakukan antara lain berupa perlindungan sumber daya alam dan pengesahan payung hukum dalam pengembangan ekowisata; penguatan kapasitas masyarakat daerah penyangga; serta peningkatan koordinasi, peran, dan kemitraan antarinstansi Pemerintah, swasta, dan stakeholder lainnya. Melalui strategi tersebut diharapkan dapat meningkatkan keberdayaan masyarakat 
daerah penyangga melalui pengembangan ekowisata tanpa merusak site-site ekowisata yang ada karena faktor-faktor kunci kesuksesan pemberdayaan masyarakat melalui pengembangan ekowisata di antaranya berupa regulasi terkait konservasi dan pengaturan kelembagaan; kesadaran lingkungan dan partisipasi masyarakat yang tinggi; serta kemitraan dan kolaborasi antarstakeholder (Hiwasaki, 2006; Okazaki, 2008; Obua, dkk, 2007).

\section{PERNYATAAN RESMI}

Ucapan terima kasih Penulis tujukan pada semua pihak yang telah berperan dalam penelitian ini terutama warga masyarakat daerah penyangga TNGMb yang telah berkenan memberikan informasi, Ibu Maya Damayanti, ST, MA, PhD yang telah memberikan masukan dan arahan, serta Pusbindiklatren Bappenas yang telah menjadi sponsor untuk pendanaan dalam penelitian ini.

\section{REFERENSI}

Direktorat Pemanfaatan Jasa Lingkungan dan Wisata Alam. (2010). Pedoman Pengelolaan Pemberdayaan Masyarakat di Daerah Penyangga. Bogor: Direktorat Pemanfaatan Jasa Lingkungan dan Wisata Alam.

Damanik, J. dan H. F. W. (2006). Perencanaan Ekowisata, dari Teori ke Aplikasi. Yogyakarta: Andi.

Goodwin, H., \& Roe, D. (2001). Tourism, livelihoods and protected areas: opportunities for fair-trade tourism in and around National parks. International Journal of Tourism Research, 3(5), 377-391. https://doi.org/10.1002/jtr.350

Hiwasaki, L. (2006). Community-based tourism: A pathway to sustainability for Japan's protected areas. Society and Natural Resources, 19(8), 675-692. https://doi.org/10.1080/08941920600801090

Jaafar, M., Bakri, N. M., \& Rasoolimanesh, S. M. (2015). Local Community and Tourism Development: A Study of Rural Mountainous Destinations. Modern Applied Science, 9(8), 399-408. https://doi.org/10.5539/mas.v9n8p399

Departemen Kehutanan. (2008). Pedoman Kriteria dan Indikator Pemberdayaan Masyarakat di Sekitar Kawasan Konservasi. Bogor: Departemen Kehutanan - Direktorat Pemanfaatan Jasa Lingkungan dan Wisata Alam.

Kiss, A. (2004). Is community-based ecotourism a good use of biodiversity conservation funds? Trends in Ecology and Evolution, 19(5), 232-237. https://doi.org/10.1016/j.tree.2004.03.010

Miles, M. B. dan Huberman, A. M. (1992). Analisis Data Kualitatif: Buku Sumber tentang Metode-Metode Baru. Terjemahan Tjetjep Rohendi R. Jakarta: Penerbit Universitas Indonesia.

Moleong, J. (2012). Metode Penelitian Kualitatif (Edisi Revisi). Bandung: Rosdakarya.

Obua, J., D. (2007). Enhancing Rural Livelihoods Through Sustainable Community Tourism (CIDA Project). Report on The Reconaissance Trip to Communities Neighboring Protected Areas in Western Uganda. Makerere University: University of Manitoba.

Okazaki, E. (2008). A community-based tourism model: Its conception and use. Journal of Sustainable Tourism, 16(5), 511-529. https://doi.org/10.1080/09669580802159594

Oladeji, S. O. (2015). Community Based Ecotourism Management Practise, A Panacea for Sustainable Rural Development in Liberia. Journal of Research in Forestry, Wildlife and Environmental, 7(1), 136-153.

Petrić, L., \& Mandić, A. (2014). Visitor Management Tools for Protected Areas Focused on Sustainable Tourism Development: the Croatian Experience. Environmental Engineering and Management Journal, 13(6), 1483-1495. Retrieved from http://omicron.ch.tuiasi.ro/EEMJ/

Setyadi, I. A., Hartoyo, Maulana, A., \& Muntasib, E. K. H. (2012). Strategi Pengembangan Ekowisata Di Taman Nasional Sebangau Kalimantan Tengah. Jurnal Manajemen \& Agribisnis.

Situmorang, D. B. M., \& Mirzanti, I. R. (2012). Social Entrepreneurship to Develop Ecotourism. Procedia Economics and Finance, 4(Icsmed), 398-405. https://doi.org/10.1016/S2212-5671(12)00354-1

Suarka, F. M. (2011). Identifikasi Potensi dan Program Pengembangan Produk Ekowisata di Desa Tingihan, Kecamatan Banjarangkan, Kabupaten Klungkung., 6(2), 121-127. 
Sumaryadi, I. N. (2005). Perencanaan Pembangunan Daerah Otonomi dan Pemberdayaan Masyarakat. Jakarta: Citra Utama.

The International Ecotourism Society (TIES). (2015). What is Ecotourism? Retrieved from https://www.ecotourism.org/what-is-ecotourism.

Wearing, S. dan Neil, J. (2009). Ecotourism: Impacts, Potentials and Possibilities (Second Edition). Oxford: Butterworth - Heinemann (Elsevier). 